\title{
Evaluation of Inflammation with Neutrophil-to-lymphocyte Ratio and Platelet-to-lymphocyte Ratio in Restless Legs Syndrome
}

\author{
Huzursuz Bacaklar Sendromunda Enflamasyonun Nötrofil-lenfosit ve Trombosit-lenfosit \\ Oranları ile Değerlendirilmesi
}

\author{
(1) Ali Zeynal Abidin Tak ${ }^{1}$, (1) Yıldızhan Şengül ${ }^{2}$ \\ ${ }^{1}$ Adiyaman University Faculty of Medicine, Department of Neurology, Adiyaman, Turkey \\ ${ }^{2}$ Bezmialem Foundation University Faculty of Medicine, Department of Neurology, Istanbul, Turkey
}

\begin{abstract}
Objective: Restless legs syndrome (RLS) is a chronic, progressive sensorimotor disorder characterized by an irresistible urge to move the extremities-especially the legs-and abnormal sensations. Although symptoms are observed during the night at the initial stage of the disease, as the disease progresses, they can be observed at rest during the day. It is seen in 5-15\% of the population. We aimed to evaluate the neutrophil-to-lymphocyte ratio (NLR) and platelet-to-lymphocyte ratio and systemic inflammation in patients with RLS based on the hypothesis that inflammatory mechanisms may play a role in the pathophysiology of RLS.

Materials and Methods: A total of 62 patients with RLS and 40 healthy volunteers were included in the study and the sociodemographic characteristics of both groups were examined. Routine biochemistry and hemogram studies were performed on all patients. NLR was obtained by dividing the absolute number of neutrophils by the number of lymphocytes and PLR by dividing the absolute platelet count by the lymphocyte count.

Results: When the NLR levels were evaluated, no significant difference was found between the patient group $(1.80 \pm 1.10)$ and the control group (2.01 \pm 0.67$)$ $(\mathrm{p}=0.26)$. PLR was higher in the RLS group $(104.86 \pm 46.52)$ than in the control group $(97.78 \pm 39.09)$, but it was not statistically significant $(\mathrm{p}=0.45)$. When vitamin B12 and folate levels were evaluated, there was no significant difference between the patient and control groups. Ferritin levels were significantly lower in the patient group $(\mathrm{p}=0.03)$.

Conclusion: When we evaluated NLR and PLR in the patients with RLS, it was determined that there was no significant difference in either parameter. It can be assumed that hematologic parameters such as neutrophils, lymphocytes, and platelets are easily affected by various conditions, or may be due to the small number of patients. Identifying new bio-indicators that will probably show systematic inflammation and neuro inflammation will clarify this issue in the future.
\end{abstract} Keywords: Restless legs syndrome, neutrophil-to-lymphocyte ratio, platelet-to-lymphocyte ratio

$\ddot{O} \mathbf{z}$

Amaç: Huzursuz bacaklar sendromu (HBS); ekstremitelerde öncelikle bacaklarda hareket ettirme dürtüsü ve anormal duyularla karakterize, kronik, ilerleyici sensorimotor bir bozukluktur. Semptomların başlangıcı gece olsa da hastalık ilerledikçe gün içindeki hareketsiz dönemlerde de görülebilir. Nüfusun \%5-15 kadarında görülür. Çalışmamızda HBS patofizyolojisinde enflamatuvar mekanizmaların rolü olabileceği hipotezinden hareketle HBS olan hastalarda nötrofillenfosit oranı (NLR) ve trombosit-lenfosit oranı (PLR) ile sistemik enflamasyonu değerlendirmeyi amaçladık.

Gereç ve Yöntem: Toplam 62 HBS hastası ile 40 sağlıklı gönüllü çalışmaya alınarak her iki gruba ait sosyo-demografik özellikler incelendi. Tüm hastaların rutin biyokimya ve hemogram incelemeleri yapıldı. NLR, mutlak nötrofil sayısının lenfosit sayısına bölünmesi ile, PLR ise mutlak trombosit sayısının lenfosit sayısına bölünmesi ile elde edildi.

Bulgular: NLR düzeyleri de ğerlendirildiğinde hasta grubuyla $(1,80 \pm 1,10)$ kontrol grubu $(2,01 \pm 0,67)$ arasında anlamlı fark saptanmadı $(\mathrm{p}=0,26)$. PLR de $\breve{g}$ eri ise; HBS grubunda $(104,86 \pm 46,52)$ kontrol grubuna göre yüksek seviyede $(97,78 \pm 39,09)$ olmasına rağmen anlamlı değildi ( $(p=0,42)$. Vitamin B12 ve folat seviyeleri değerlendirildiğinde hasta ve kontrol grupları arasında anlamlı bir fark bulunmadı. Ferritin düzeyleri ise hasta grubunda anlamlı derecede düşüktü $(\mathrm{p}=0,03)$.

Sonuç: HBS olan hastalarda NLR ve PLR ile birlikte değerlendirildiğinde her iki parametre için anlamlı bir artış olmadığı saptandı. Bu durumun nötrofil, lenfosit ve trombosit sayısı gibi hematolojik parametrelerin çeşitli durumlardan kolayca etkilenebiliyor olmasından ya da hasta sayısının az olmasından kaynaklanabileceğini düşünüyoruz. Gelecekte sistemik enflamasyonu ve nöroenflamasyonu göstermesi muhtemel yeni biyobelirteçlerin saptanması bu duruma açıklık getirecektir.

Anahtar Kelimeler: Huzursuz bacaklar sendromu, nötrofil-lenfosit oranı, trombosit-lenfosit oranı

Address for Correspondence/Yazışma Adresi: Ali Zeynal Abidin Tak MD, Adiyaman University Faculty of Medicine, Department of Neurology, Adiyaman, Turkey Phone: +90 5306061932 E-mail: atak@adiyaman.edu.tr ORCID ID: orcid.org/0000-0002-3783-184X

Received/Geliş Tarihi: 09.11.2017 Accepted/Kabul Tarihi: 25.03.2018

${ }^{\oplus}$ Copyright 2018 by Turkish Neurological Society

Turkish Journal of Neurology published by Galenos Publishing House. 


\section{Introduction}

Restless legs syndrome (RLS) is a chronic, progressive sensorymotor neurologic disorder that worsens at nights and disrupts the quality of sleep, which presents with the urge or desire to move the legs and is characterized by abnormal senses $(1,2)$. RLS, also known as Willis-Ekbom disease, was first described by Dr. Ekbom (3) in 1945. The diagnostic criteria of RLS were defined by the International Restless Legs Syndrome Study Group (IRLSSG). These criteria were updated by the same group in 2014 and the number of the criteria was increased up to 5 from 4 . For "not definite" patients with RLS, four supporting features, markers related to clinical course and significance were defined in 2014. These criteria were as follows:

1. An urge to move the legs, usually but not always accompanied by, or felt to be caused by, uncomfortable and unpleasant sensations in the legs.

2. The urge to move the legs and any accompanying unpleasant sensations begin or worsen during periods of rest.

3. The urge to move the legs and any accompanying unpleasant sensations are partially or totally relieved by movement, such as walking or stretching.

4. The urge to move the legs and any accompanying unpleasant sensations during rest or inactivity only occur or are worse in the evening or night than during the day.

5. The occurrence of the above features is not solely accounted for as symptoms primary to another medical or a behavioral condition (e.g. myalgia, venous stasis, leg edema, arthritis, leg cramps, positional discomfort, habitual foot tapping) (1).

Its frequency has been found as between $0.25-15.3 \%$ in studies using the international diagnostic criteria. It is more common in women and its frequency increases with age (4). In a multi-center study in which the epidemiology of sleep disorders in Turkey was investigated by the Turkish Sleep Medicine Society, the frequency of RLS in men was 3\% and in women it was $7.3 \%$ (5). RLS can be seen primarily or secondarily due to disorders and conditions including iron deficiency, chronic renal failure, and pregnancy (6).

The etiology of the disorder is still not well known (7). It is thought to be caused by dopaminergic dysfunction (8). However, recent studies have found a relation between RLS and inflammatory diseases, including systemic lupus erythematosus, Chron's disease, celiac disease $(9,10,11,12)$, and the potential role of inflammation in etiology has been discussed. Hypoxia-inducible factor-1 $\alpha$ $(\mathrm{HIF}-1 \alpha)$ acts as a regulator in inflammation (13). High levels of HIF- $1 \alpha$ in the neurons of the substantia nigra in patients with RLS was shown by Patton et al. (14), which highlights the role of inflammation at a cellular level in RLS. The neutrophil-tolymphocyte ratio (NLR) and platelet-to-lymphocyte ratio (PLR) have been used as markers of systemic inflammation recently. NLR and PLR measurements cost less than other inflammatory markers, and it is practical and easy to perform $(7,15)$. In cases of various acute and chronic inflammatory conditions, NLR and PLR were found high in studies, and in the only study which studied NLR in patients with RLS, it was found that NLR was higher in the study group (7). PLR is also a marker of systemic inflammation and some studies showed that if PLR and NLR were used together they became more determinative $(16,17,18)$.
In this study, considering the hypothesis that inflammation might play a role in the pathogenesis of RLS, different from the only study in the literature, which assessed inflammation by using NLR in RLS, we aimed to assess inflammation by using both the NLR and PLR in the patients with RLS. Also, we measured serum levels of B12, folate, and ferritin, which have a well-known association with the disease.

\section{Materials and Methods}

This study was a retrospective case series comparing a patient group with primary RLS and a control group consisting of healthy subjects. Sixty-two patients (30 males, 32 females) aged between 18 and 55 years who were followed up in the Clinic of Neurology in Adiyaman University and were diagnosed as having primary RLS according to the IRLSSG 2014 criteria (1) and 40 healthy subjects (18 males, 22 females) between the ages of 18 and 55 years were included in the study. Sociodemographic features (e.g., age, sex, marital status) of both groups were investigated. Biochemical tests and hemograms of the patients were assessed. Patients with polyneuropathy, lumbosacral radiculopathy, amyotrophic lateral sclerosis, multiple myeloma, multiple sclerosis, Parkinson's disease, poliomyelitis, diabetes mellitus, uremia, amyloidosis, cancer, peripheral vascular diseases, pulmonary disease, congestive heart failure, Cushing's syndrome, hypo- or hyperthyroidism, pregnancy, lactation, chronic kidney failure, neuroleptic or antidepressant usage, cigarette smoking, steroid treatment (for whatever reason), systemic inflammatory diseases, and hematologic diseases were excluded. NLR was obtained by dividing the absolute number of neutrophils by the number of lymphocytes. PLR was obtained by dividing the absolute platelet count by the number of lymphocytes. The approval was obtained from Biomedical Researches Ethics Committee of Faculty of Medicine' Decanate of T.C. Adiyaman University (approval no: 2017/2-3, date: 20.04.2017).

\section{Statistical Analysis}

Average, percentage, frequency, and frequency analysis were used as descriptive statistics in the evaluation of the data. Fisher's exact test and Pearson's chi-square test were used to comparing the counts. The normal distribution of the data was evaluated using the Shapiro-Wilk test. The independent samples t-test was used in comparisons. A p value of $<0.05$ was considered statistically significant. The correlation between NLR and PLR values and ferritin levels was evaluated using multiple regression analysis. The study data were analyzed using the SPSS version 21.0 pocket program (version 21.0, Microsoft Inc., Chicago, IL, USA).

\section{Results}

One hundred two participants including 62 patients with primary RLS and 40 controls were included in the study. Both groups had similar sociodemographic features. Of the patients with RLS, 30 (48.39\%) were males and 32 (51.61\%) were females. The average age of the patients with RLS was $41.61 \pm 10.92$ years. Of the healthy subjects, $18(45 \%)$ were males and $22(55 \%)$ were females. The average age of the healthy subjects was $41.55 \pm 9.10$ years. The sociodemographic data are shown in Table 1.

The NLR was $1.80 \pm 1.10$ in the RLS group and $2.01 \pm 0.67$ in the control group. There was no statistically significant difference 
between the groups $(\mathrm{p}=0.29)$. The PLR was $104.86 \pm 46.52$ in the RLS group and $97.78 \pm 39.09$ in the control group. There was no statistically significant difference between the groups $(\mathrm{p}=0.45)$. There was no statistically significant difference between the groups in terms of vitamin B12 and folate levels. The hematologic parameters of the patient and control groups are presented in Table 2. Ferritin levels were significantly lower in the RLS group $(\mathrm{p}=0.03)$. There was a statistically significant correlation between NLR and PLR values and ferritin levels in the RLS group $(\mathrm{p}=0.003$ and 0.001 , respectively). We could not calculate a cut-off value with ROC analysis because there was no significant correlation between NLR values and the disease.

\section{Discussion}

The pathophysiology of RLS is not well described, but various hypotheses such as dopaminergic hyperstimulation, iron deficiency, insensitivity of dopaminergic receptors in the tubero-infindibular area have been suggested (19). However, the role of systemic inflammation in the pathogenesis of RLS has been discussed in some studies recently. The coexistence of RLS with some diseases related with systemic inflammation such as systemic lupus erythematosus, rheumatoid arthritis, human immunodeficiency virus infection, and inflammatory bowel disease was shown and the association of RLS with immunologic and inflammatory mechanisms was highlighted $(9,10,11,12,20)$.

NLR and PLR are new, cost-effective and simple methods used to assess inflammation. High levels of NLR and/or PLR were shown in acute or chronic inflammatory conditions such as acute pancreatitis (21), chronic tonsillitis (22), acute mesenteric ischemia (23), coronary artery disease (24), diabetes mellitus

\begin{tabular}{|c|c|c|c|}
\hline Parameter & $\begin{array}{l}\text { RLS group } \\
(n=62)\end{array}$ & $\begin{array}{l}\text { Control } \\
\text { group }(n=40)\end{array}$ & $\mathrm{p}$ value \\
\hline $\begin{array}{l}\text { Male } \\
\text { Female }\end{array}$ & $\begin{array}{l}30(45 \%) \\
32(55 \%)\end{array}$ & $\begin{array}{l}18(48.39 \%) \\
22(51.61 \%)\end{array}$ & $\mathrm{p}=0.84$ \\
\hline Age & $41.61 \pm 10.92$ & $41.55 \pm 9.10$ & $\mathrm{p}=0.98$ \\
\hline
\end{tabular}

(25), heart failure (26) and malignancies $(27,28)$. Also, NLR was evaluated in some central or systemic neurologic diseases including ischemic and hemorrhagic cerebrovascular diseases, myasthenia gravis and multiple sclerosis and was correlated with prognosis $(29,30,31,32)$. In addition, some studies showed that RLS was more common in neurologic conditions in which the NLR was found increased $(33,34,35)$.

The only study in the literature that evaluated inflammation with the NLR in patients with RLS showed higher NLR values in the RLS group, and the authors discussed the effect of inflammation in the etiology (7). To investigate the role of inflammation in the etiology of RLS, we measured PLR in addition to NLR and found no significant increase in either parameter in the RLS group. Improvement in symptoms with dopamine agonists and worsening in symptoms with anti-dopaminergic agents are known. This worsening is marked with dopamine antagonists that can cross the blood brain barrier such as metoclopramide and no worsening is seen with dopamine antagonists that cannot cross the blood brain barrier. This finding suggests that RLS is caused by central nervous system (CNS) dysfunction and not peripheral nervous system dysfunction (8). Patton et al. (14) showed higher levels of HIF$1 \alpha$, which acts as a regulator in inflammation in the substantia nigra of patients with RLS, indicating the effect of inflammation at cellular level. Different from the study of Varım et al. (7), we found no relationship between NLR and PLR levels and RLS and found lower NLRs in the RLS group, which might be explained as follows: systemic inflammation is not included in the etiology of RLS in addition to inflammation in CNS. In addition, hematologic parameters such as neutrophil, lymphocyte, and platelet counts can easily be affected by various conditions such as ethnicity, age, sex, eating habits, and environmental factors (36). Also, the small number of patients in our study may have contributed to our negative results. Vitamin B12, folate, and ferritin levels were found normal in the study of Varım et al. (7), but in their study these values were significantly different between the patient and control groups. We found no such result in our study. Although ferritin levels were lower in the RLS group compared with the control group, the difference was not statistically significant. This finding may also be due to the replacement treatments that patients might have taken before. However, the relationship between systemic inflammation and ferritin has been shown in many studies (37).

Table 2. Hematologic parameters of the patient and control groups

\begin{tabular}{lllll} 
Parameter & RLS group $(\mathrm{n}=62)$ & Control group $(\mathrm{n}=40)$ & Normal limits & $\mathrm{p}$ value \\
Hemoglobin $(\mathrm{g} / \mathrm{dL})$ & $14.19 \pm 1.93$ & $14.63 \pm 2.25$ & $12.2-18.1$ & 0.29 \\
Hematocrit $(\%)$ & $43.25 \pm 5.19$ & $43.72 \pm 6.05$ & $37.7-53.7$ & 0.67 \\
Leucocyte $(\mathrm{K} / \mu \mathrm{L})$ & $7.95 \pm 1.94$ & $9.22 \pm 2.24$ & $4.6-10.2$ & $<0.01$ \\
Neutrophil $(\mathrm{K} / \mu \mathrm{L})$ & $4.39 \pm 1.41$ & $5.47 \pm 1.55$ & $2.0-6.9$ & $<0.01$ \\
Lymphocyte $(\mathrm{K} / \mu \mathrm{L})$ & $2.7 \pm 0.83$ & $2.87 \pm 0.76$ & $0.6-3.4$ & 0.28 \\
Platelet $(\mathrm{K} / \mu \mathrm{L})$ & $256.26 \pm 54.76$ & $260.69 \pm 63.96$ & $142-424$ & 0.71 \\
NLR & $1.80 \pm 1.10$ & $2.01 \pm 0.67$ & - & 0.26 \\
PLR & $104.86 \pm 46.53$ & $97.78 \pm 39.09$ & - & 0.43 \\
RLS: Restless legs syndrome, NLR: Neutrophil-to-lymphocyte ratio, PLR: Platelet-to-lymphocyte ratio & & \\
\hline
\end{tabular}


We also found a significant correlation between ferritin levels and NLR and PLR values.

\section{Study Limitations}

C-reactive protein, sedimentation and other biomaterials such as interleukin-6 were not evaluated and the number of patients was low, which were the limitations of our study.

\section{Conclusion}

In conclusion, in this study, we evaluated the role of inflammation in the pathophysiology of RLS with NLR and PLR, and found no significant association for inflammation in the patient group. Multi-center and longitudinal studies are needed.

\section{Ethics}

Ethics Committee Approval: The approval was obtained from Biomedical Researches Ethics Committee of Faculty of Medicine' Decanate of T.C. Adiyaman University (approval no: 2017/2-3, date: 20.04.2017) for retrospective case study.

Informed Consent: This is a retrospective case study.

Peer-review: Externally and internally peer-reviewed.

\section{Authorship Contributions}

Concept: A.Z.A.T., Design: A.Z.A.T., Y.Ş., Data Collection or Processing: A.Z.A.T., Analysis or Interpretation: Y.Ş., Literature Search: A.Z.A.T., Writing: A.Z.A.T., Y.Ş.

Conflict of Interest: Authors did not report any conflict of interest.

Financial Support: No financial support was received from any institution or person for our study.

\section{References}

1. Allen RP, Picchietti DL, Garcia-Borreguero D, et al. Restless legs syndrome/ Willis-Ekbom disease diagnostic criteria: updated International Restless Legs Syndrome Study Group (IRLSSG) consensus criteria--history, rationale, description, and significance. Sleep Med 2014;15:860-873

2. Trenkwalder C, Paulus W, Walters AS. The restless legs syndrome. Lancet Neurol 2005;4:465-475.

3. Ekbom K. Restless legs: a clinical study. Acta Med Scand Suppl 1945;158:1123

4. Ghorayeb I, Tison F. Epidemiology of restless legs syndrome. Rev Neurol (Paris) 2009; 165:641-649.

5. Demir AU, Ardıc S, Firat H, et al. Prevalence of sleep disorders in the Turkish adult population epidemiology of sleep study. Sleep and Biological Rhytmes 2015;13:298-308.

6. Winkelman JW, Armstrong MJ, Allen RP, et al. Practice guideline summary: Treatment of restless legs syndrome in adults: Report of the Guideline Development, Dissemination, and Implementation Subcommittee of the American Academy of Neurology. Neurology 2016;87:2585-2593.

7. Varım C, Acar BA, Uyanık MS, et al. Association between the neutrophil-tolymphocyte ratio, a new marker of systemic inflammation, and restless legs syndrome. Singapore Med J 2016;57:514-516.

8. Allen RP. Controversies and challenges in defining the etiology and pathophysiology of restless legs syndrome. Am J Med 2007;120(Suppl 1):1321.

9. Hassan N, Pineau CA, Clarke AE, Vinet E, Ng R, Bernatsky S. Systemic lupus and risk of restless legs syndrome. J Rheumatol 2011;38:874-876.

10. Gjevre JA, Taylor Gjevre RM. Restless legs syndrome as a comorbidity in rheumatoid arthritis. Autoimmune Dis 2013;2013:352782.
11. Weinstock LB, Bosworth BP, Scherl EJ, et al. Crohn's disease is associated with restless legs syndrome. Inflamm Bowel Dis 2010;16:275-279.

12. Weinstock LB, Walters AS, Mullin GE, Duntley SP. Celiac disease is associated with restless legs syndrome. Dig Dis Sci 2010; 55:1667-1673.

13. Imtiyaz HZ, Simon MC. Hypoxia-inducible factors as essential regulators of inflammation. Curr Top Microbiol Immunol 2010;345:105-120.

14. Patton SM, Ponnuru P, Snyder AM, Podskalny GD, Connor JR. Hypoxiainducible factor pathway activation in restless legs syndrome patients. Eur J Neurol 2011;18:1329-1335.

15. Wang YQ, Zhi QJ, Wang XY, Yue DS, Li K, Jiang RC. Prognostic value of combined platelet, fibrinogen, neutrophil to lymphocyte ratio and platelet to lymphocyte ratio in patients with lung adenosquamous cancer. Oncol Lett 2017;14:4331-4338

16. Zhao QT, Zhang XP, Zhang H, Duan GC. Prognostic role of platelet to lymphocyte ratio in esophageal cancer: A meta-analysis. Oncotarget 2017;8:112085-112093.

17. Ming L, Jiang Z, Ma J, Wang Q, Wu F, Ping J. Platelet-to-lymphocyte ratio, neutrophil-to-lymphocyte ratio, and platelet indices in patients with acute deep vein thrombosis. Vasa 2018;47:143-147.

18. Chen K, Zhan MX, Hu BS, et al. Combination of the neutrophil to lymphocyte ratio and the platelet to lymphocyte ratio as a useful predictor for recurrence following radiofrequency ablation of hepatocellular carcinoma. Oncol Lett 2018;15:315-323.

19. Rye DB. Parkinson's disease and RLS: the dopaminergic bridge. Sleep Med 2004;5:317-328.

20. Happe S, Kundmüller L, Reichelt D, Husstedt IW, Evers S. Comorbidity of restless legs syndrome and HIV infection. J Neurol 2007;254:1401-1406.

21. Suppiah A, Malde D, Arab T, et al. The prognostic value of the neutrophillymphocyte ratio (NLR) in acute pancreatitis: identification of an optimal NLR. J Gastrointest Surg 2013;17:675-681.

22. Yenigun A. The efficacy of tonsillectomy in chronic tonsillitis patients as demonstrated by the neutrophil-to-lymphocyte ratio. J Laryngol Otol 2015;129:386-391.

23. Aktimur R, Cetinkunar S, Yildirim K, Aktimur SH, Ugurlucan M, Ozlem N Neutrophil-to-lymphocyte ratio as a diagnostic biomarker for the diagnosis of acute mesenteric ischemia. Eur J Trauma Emerg Surg 2016;42:363-368.

24. Kaya H, Ertaş F, İslamoğlu $\mathrm{Y}$, et al. Association between neutrophil to lymphocyte ratio and severity of coronary artery disease. Clin Appl Thromb Hemost 2014;20:50-54.

25. Lou M, Luo P, Tang R, et al. Relationship between neutrophil-lymphocyte ratio and insulin resistance in newly diagnosed type 2 diabetes mellitus patients. BMC Endocr Disord 2015;15:9.

26. Uthamalingam S, Patvardhan EA, Subramanian S, et al. Utility of the neutrophil to lymphocyte ratio in predicting long-term outcomes in acute decompensated heart failure. Am J Cardiol 2011;107:433-438.

27. Cho H, Hur HW, Kim SW, et al. Pre-treatment neutrophil to lymphocyte ratio is elevated in epithelial ovarian cancer and predicts survival after treatment. Cancer Immunol Immunother 2009;58:15-23.

28. Yamanaka T, Matsumoto S, Teramukai S, Ishiwata R, Nagai Y, Fukushima M. The baseline ratio of neutrophils to lymphocytes is associated with patient prognosis in advanced gastric cancer. Oncology 2007;73:215-220.

29. Yang DH, Qian MZ, Wei MM, et al. The correlation of neutrophil-tolymphocyte ratio with the presence and activity of myasthenia gravis. Oncotarget 2017;8:76099-76107.

30. Saliba W, Barnett-Griness O, Elias M, Rennert G. Neutrophil to lymphocyte ratio and risk of a first episode of stroke in patients with atrial fibrillation: a cohort study. J Thromb Haemost 2015;13:1971-1979.

31. Lattanzi S, Cagnetti C, Provinciali L, Silvestrini M. Neutrophil-to-lymphocyte ratio and neurological deterioration following acute cerebral hemorrhage. Oncotarget 2017;8:57489-57494. 
32. Bisgaard AK, Pihl-Jensen G, Frederiksen JL. The neutrophil-to-lymphocyte ratio as disease actvity marker in multiple sclerosis and optic neuritis. Mult Scler Relat Disord 2017;18:213-217.

33. Schlesinger I, Erikh I, Nassar M, Sprecher E. Restless legs syndrome in stroke patients. Sleep Med 2015;16:1006-1010.

34. Sieminski M, Bilinska M, Nyka WM. Increased frequency of restless legs syndrome in myasthenia gravis. Eur Neurol 2012;68:166-170.
35. Sorgun MH, Aksun Z, Atalay YB, Yücesan C. Restless legs syndrome in multiple sclerosis. Turk J Med Sci 2015;45:1268-1273.

36. El-Hazmi MA, Warsy AS. Normal reference values for hematological parameters, red cell indices, HB A2 and HB F from early childhood through adolescence in Saudis. Ann Saudi Med 2001;21:165-169.

37. Weinstock LB, Walters AS, Paueksakon P. Restless legs syndrome--theoretical roles of inflammatory and immune mechanisms. Sleep Med Rev 2012;16:341354. 